\title{
Assessment of Fine Needle Aspiration Specimen Adequacy for High-Risk HPV Detection and Genotyping in Oropharyngeal Squamous Cell Carcinoma
}

\author{
Charalambos C. Solomides Marluce Bibbo Zi-Xuan Wang \\ Department of Pathology, Anatomy and Cell Biology, Thomas Jefferson University, Philadelphia, Pa., USA
}

\section{Key Words}

Fine needle aspiration · HPV · Genotyping $\cdot$ Squamous cell carcinoma

\begin{abstract}
Objective: The aim of this study was to determine the adequacy of archived and fresh fine needle aspiration (FNA) specimens from metastatic head and neck squamous cell carcinoma (SCC) for the molecular detection and genotyping of high-risk (HR) HPV. Study Design: Thirty-seven specimens from 26 patients diagnosed by FNA with metastatic SCC were included as retrospective specimens [19 slides stained with Papanicolaou (Pap) and 18 with Diff-Quik ${ }^{\circledR}$ (DQ)]. Twenty fresh FNA specimens from 18 patients were included as prospective specimens. These specimens were analyzed using the standard protocol for ThinPrep ${ }^{\circledR}$ cervical specimens, with a Cervista HR HPV detection kit. The positive specimens were tested for the HPV 16 and 18 genotypes. $\boldsymbol{R e}$ sults: Forty-four of 57 specimens (77\%) had sufficient cells to yield a valid HPV result. The adequacy rate for Pap-stained slides was 15/19 (79\%), for DQ-stained slides it was 13/18 (72\%), and for fresh needle aspirates it was 16/20 (80\%). HR HPV was detected in 23/44 (52\%) specimens. Among the 23 HPV-positive specimens, 19 were genotyped as HPV 16 and 1 as HPV 18. Conclusions: HR HPV detection and genotyping
\end{abstract}

can be performed on FNA specimens of head and neck SCC prospectively collected in PreservCyt as well as on archival slides with either Pap or DQ stain.

Copyright $\odot 2012$ S. Karger AG, Basel

\section{Objective}

Head and neck squamous cell carcinoma (HNSCC) is a heterogeneous tumor group. One recently recognized subtype is the HPV-positive oropharyngeal carcinoma (OPC).

The HPV-positive OPC shows increasing incidence and usually affects younger patients, predominantly white males, non-cigarette smokers, non-alcohol drinkers, and individuals with a high number of sexual partners and a history of oral-genital or oral-anal sex [1].

These tumors usually arise from the crypts of the lingual and palatine tonsils, have no association with dysplasia of the surface squamous epithelium, show a lobular growth pattern, and demonstrate basaloid morphology, lacking significant keratinization.

Presented at the 2011 ASC Annual Meeting in Baltimore, Md., USA, on November 6, 2011, as a platform presentation.

\section{KARGER}

Fax +4161306 1234 E-Mail karger@karger.ch www.karger.com
(C) 2012 S. Karger AG, Basel

0001-5547/12/0562-0196\$38.00/0

Accessible online at:

www.karger.com/acy
Correspondence to: Dr. Charalambos C. Solomides

Department of Pathology, Thomas Jefferson University Hospital

132 S. 10th Street, Suite 260A, Main Building

Philadelphia, PA 19107 (USA)

Tel. +1 215503 6202, E-Mail charalambos.solomides@jefferson.edu 
Table 1. FNA specimen adequacy for HR HPV

\begin{tabular}{lllll}
\hline \multicolumn{5}{c}{ Specimen type } \\
& $\begin{array}{l}\text { Pap-scraped } \\
\text { cells }\end{array}$ & $\begin{array}{l}\text { DQ-scraped } \\
\text { cells }\end{array}$ & $\begin{array}{l}\text { Fresh in } \\
\text { PreservCyt }\end{array}$ & Total \\
\hline Samples, n & 19 & 18 & 20 & $57(100 \%)$ \\
Adequate & $15(79 \%)$ & $13(72 \%)$ & $16(80 \%)$ & $44(77 \%)$ \\
Low gDNA & $4(21 \%)$ & $5(28 \%)$ & $4(20 \%)$ & $23(23 \%)$ \\
\hline
\end{tabular}

Table 2. HR HPV and HPV 16 results

\begin{tabular}{ll}
\hline Adequate specimens & $44(100 \%)$ \\
HR HPV+ & $23(52 \%)$ \\
\hline HR HPV+ & $23(100 \%)$ \\
HPV $16+$ & $19(83 \%)$ \\
\hline
\end{tabular}

Table 3. HR HPV and HPV 16 results

\begin{tabular}{lclll}
\hline & $\begin{array}{l}\text { HR HPV } \\
(\mathrm{n}=23)\end{array}$ & $\begin{array}{l}\text { HR HPV } \\
(\mathrm{n}=21)\end{array}$ & $\begin{array}{l}\text { Total } \\
(\mathrm{n}=44)\end{array}$ & $\begin{array}{l}\text { HPV 16+ genotype } \\
(\mathrm{n}=19)\end{array}$ \\
\hline Pap-scraped cells & $8(53 \%)$ & 7 & 15 & $8(100 \%)$ \\
DQ-scraped cells & $5(38 \%)$ & 8 & 13 & $4(80 \%)(1 \mathrm{HPV} 18+)$ \\
Fresh in PreservCyt & $10(63 \%)$ & 6 & 16 & $7(70 \%)$ \\
\hline
\end{tabular}

HPV-positive HNSCC express the viral oncoproteins E6 and E7, they overexpress P16 gene product, and they infrequently harbor $\mathrm{p} 53$ gene mutations and are associated with an improved prognosis [2]. Tumor HPV status is a strong and independent prognostic factor for survival among individuals with OPC in nonsmoking patients [3]. HPV 16 has been detected in up to $70 \%$ of OPC. The aim of this study was to determine the adequacy of archival and fresh FNA specimens for molecular detection and genotyping of HPV using Cervista HR HPV detection assay.

\section{Study Design}

After obtaining approval from the institutional review board, a retrospective review of our pathology files was undertaken to identify those patients with a diagnosis of metastatic SCC in fine needle aspirations (FNA) of the head and neck area in the past 5 years. A total of 37 adequate specimens from 26 patients were available in the cytology laboratory of Thomas Jefferson University Hospital and were included as retrospective specimens. Among these specimens, 19 had slides stained with Papanicolaou (Pap) and 18 had slides stained with Diff-Quik ${ }^{\circledR}$ (DQ) stain. Twenty fresh FNA specimens from 18 patients with metastatic SCC diagnosed in the last 6 months were included as prospective specimens.

\section{HPV Analysis}

The archival Pap- and DQ-stained slides were soaked in xylene overnight to remove the coverslips. Scraped cells from the slides were placed in tubes and washed with ethanol, and dry pel- lets were resuspended in $2 \mathrm{ml}$ of PreservCyt solution. For the prospective samples, fresh residual needle material from FNA specimens was directly rinsed in $2 \mathrm{ml}$ of PreservCyt solution. All specimens were then analyzed using the standard protocol for ThinPrep ${ }^{\circledR}$ cervical specimens with a Cervista HR HPV detection kit. Positive specimens were then tested for HPV 16 and 18 genotypes.

\section{Results}

Overall 44 of 57 specimens (77\%) had a sufficient number of cells to yield a valid HPV result. The adequacy rate for Pap-stained slides was 15/19 (79\%), for DQstained slides it was $13 / 18(72 \%)$, and for fresh needle aspirates it was 16/20 (80\%) (table 1). High-risk (HR) HPV was detected in 23/44 (52\%) specimens. Identical HR HPV results were obtained from parallel DQ- and Papstained specimens in 6 patients. Among the $23 \mathrm{HPV}$-positive specimens, 19 (83\%) were genotyped as HPV 16 and 1 was HPV 18 (tables 2, 3).

\section{Discussion}

HPV genotyping has been used in gynecologic cytopathology in the past few years $[4,5]$ but only recently is emerging as an important tool in the management of patients with OPC. Most publications in the literature are based on HPV 16 detection in surgical pathology speci- 
mens and use HPV detection methods such as PCR and ISH [6-10].

Cervista HPV HR testing has analytical sensitivity comparable to that of Hybrid Capture 2 (HC2). The assay uses a housekeeping gene as an internal control to ensure sufficient cells are tested to avoid false-negative results.

Our adequacy results (77\%) are comparable with those of one study based on HPV testing in FNA specimens performed in metastatic lesions of SCC, prior to treatment or after tumor recurrence. The authors reported the Hologic method as reliable, with adequate DNA for molecular analysis in $70 \%$ of aspirates. No genotyping data was reported [11].

The aim of our study was to determine adequacy rates for archival and fresh FNA specimens for the molecular detection and genotyping of HPV. The inclusion criteria for this study was a diagnosis of metastatic SCC in the head and neck area, not targeting only lingual and palatine tonsil SCC. This could account for the detection rates and genotyping results.

\section{Conclusion}

HR HPV detection and genotyping can be performed on FNA specimens of HNSCC prospectively collected in PreservCyt as well as on archival slides with either Pap or DQ stain.

\section{References}

1 Pai Si, Westra WH: Molecular pathology of head and neck cancer: implications for diagnosis, prognosis, and treatment. Annu Rev Pathol 2009;4:49-70.

-2 Fakhry C, Westra WH, Li S, et al: Improved survival of patients with human papillomavirus-positive head and neck squamous cell carcinoma in a prospective clinical trial. J Natl Cancer Inst 2008;100:261-269.

-3 Ang KK, Harris J, Wheeler R, et al: Human papillomavirus and survival of patients with oropharyngeal cancer. N Engl J Med 2010; 363:24-35.

4 Garcia AG, Valles AP, Martorell A, et al: The prevalence of different HPV genotypes, and the association of these infections with $\mathrm{H}-\mathrm{R}$ lesions that may progress to cervical cancer, must be considered in the design of HPV screening methods. Acta Cytol 2010;54:159164.
5 Lerma Puertas E, Salaverri CO, Martin JJ, et al: Human papillomavirus detection by PCR assay in a large series of high-grade squamous intraepithelial lesions with cytohistological correlation and follow-up. Acta Cytol 2011;55:426-432.

-6 Begum S, Gillison ML, Ansari-Lari MA, Shah K, et al: Detection of human papillomavirus in cervical lymph nodes: a highly effective strategy for localizing site of tumor origin. Clin Cancer Res 2003;9:6469-6475.

$\checkmark 7$ St Guily JL, Jacquard AC, Pretet JL, et al: Human papillomavirus genotype distribution in oropharynx and oral cavity cancer in France: the EDiTH VI study. J Clin Virol 2011;51:100-104.
8 Den Z, Hasegawa M, Matayoshi S, et al: Prevalence and clinical features of human papillomavirus in head and neck squamous cell carcinoma in Okinawa, southern Japan. Eur Arch Otorhinolaryngol 2011;268:1625-1631.

9 Chernock RD, Zhang Q, El-Mofty, et al: Human papillomavirus-related squamous cell carcinoma of the oropharynx: a comparative study in whites and African Americans. Arch Otolaryngol Head Neck Surg 2011;137: 163-169.

10 Lacau SG, Clavel C, Okais C, et al: Human papillomavirus genotype distribution in tonsil cancers. Head Neck Oncol 2011;3:6.

11 Nakashima MO, Nielsen D, van Deerlin VM, et al: How adequate are head and neck fineneedle aspiration specimens for HPV molecular analysis? An institutional experience. Cancer Cytopathol 2010;118:453A. 